\title{
The Sanctity of human life. A perspective from New Testament anthropology ${ }^{1}$
}

\section{ABSTRACT}

H C van Zyl

The article deals with sanctity of life issues such as abortion, euthanasia, treatment of the disabled, war, and capital punishment. These matters are not treated individually but collectively from the perspective of New Testament anthropology. Having taken care of a few methodological considerations, the main focus falls on a discussion of man as sinner, man in Christ, and the category of the least. The main line of thought is that man is held in high regard. Although a sinner, man is conferred a high status in Christ, and the way Jesus reached out to those at the mercy of others and gave them self-esteem and status in the eyes of God, highlights the anthropological sensitivity that should be shown in reflections on sanctity of life matters.

In mentioning "sanctity of human life", issues such as abortion, euthanasia, treatment of the disabled, war, and capital punishment spring to mind. In this article I intend to shed some light from New Testament anthropology on these matters. However, the idea is not to take these issues one by one, but rather to treat them collectively. To my mind the underlying motif binding these subjects together, is the concept of "endangered life". In one way or another, each of these matters deals with human life finding itself in a precarious situation, be it a fetus at the mercy of current thought about unborn life, or decrepit life at the mercy of society's view on what quality life is, or whole nations at the mercy of powers deciding on their destiny, or imprisoned life at the mercy of laws about suitable punishment for grievous crimes.

The keyword then is "endangered" human life which cannot decide for itself, which is delivered to and finds itself at the mercy of other human beings. How are we to view and treat this form of life from the assumption that human life is regarded as sacred by Scripture ${ }^{2}$ ? Particularly in the South Africa of our day this question takes on very special meaning, since we live in a society where human life is seemingly regarded as worthless and dispensable - not only "endangered" life, as defined above, but simply life as such. Does Scripture, and the New Testament in particular, provide us with answers to this subject? In what way does the New Testament convey the concept that human life - especially endangered life - is sacred?

Before we embark on the actual exposition of our subject, there is yet 
another introductory matter to be taken care of. It is taken for granted that the "life" of the title, which is to be regarded as sacred, is human life. Of necessity this implies a restriction, since all forms of life could rightly claim protection. In the ecological crisis we are facing on planet earth, human life is but one of many life forms which cry out for conservation. And to complicate matters even further - it is exactly through human action that life on our planet has become endangered. In a way then, in our time and age, it represents a measure of arrogance to focus on the sanctity of human life alone. Human life is interwoven with all life forms. It cannot be regarded in isolation.

Be that as it may, from a Christian point of view there is good reason to single out humankind when speaking about the sanctity of life. Indeed, one of the dictums of Christianity is that humans are the crown of creation, having been created in the image of God (Gn 1:26,27; 1 Cor 11:7; 2 Cor 3:18; cf Ps 8:5-9; Hb 2:58 ). As such they occupy a unique place. They are the only species that can consciously interact with God, their neighbour, and the environment. This does not only imply a privileged position, but also a normativeness to human existence. There is a set of conditions which is unique to humans, which, for Christians, is classically expressed in the Ten Commandments, as re-affirmed and re-interpreted in the New Testament (cf e $g$ the Sermon on the Mount, especially Mt 5:17-48). And from here flows reflection on problematic phenomena such as abortion, euthanasia, etcetera, which, in our time, often occupy the center stage of ethical discussion. It is on these issues that we would like to cast some light from a New Testament perspective.

This article is not the place to get involved in lengthy discussions about methodological matters concerning our subject. However, one cannot but mention a few problem areas which directly influence the way of arguing as well as the outcome of the study. They all pertain to the question of the usage of Scripture in modern ethical matters ${ }^{3}$, and I should at least clarify my own position in this regard before embarking on the substance of the argument itself.

Firstly, the New Testament contains no direct references to the aforementioned ethical phenomena ${ }^{4}$. It means that our subject cannot be approached in a way which deals with certain isolated texts. To my mind these issues can be best addressed in an indirect manner, that is, within the framework of the anthropology 5 of the New Testament. Even so, it is not all of (New Testament) anthropology which is in question, but a very specific area, namely what the New Testament says about endangered human life - threatened life, human life at the mercy of others. The thrust of my argument, therefore, does not involve dealing with so-called proof 
texts, but tries to establish a holistic picture or framework within which all of these problematic ethical matters might be viewed collectively and responsibly from a bibliological perspective.

This immediately evokes the second methodological consideration, which one might call the intra-relational aspect, that is, the diversity of perspectives within the New Testament, so that one could hardly speak of the anthropology of the New Testament; anthropologies of/in the New Testament would be a more apposite term. However, this does not mean that these various perspectives are so disparate that they are obfuscating or render any idea of overlapping among them impossible. To my mind there are at least certain great "trajectories" of thought about humankind in the New Testament which provide a framework within which sanctity of life problem areas might be addressed.

In its turn it highlights a third consideration, namely the inter-relational or hermeneutical. Insights pertaining to "the anthropology of the New Testament" cannot be deduced positivistically from the (diverse) extant data and applied to the problem. Rather they must be interpreted hermeneutically for their relevance today. Perhaps this constitutes the greatest challenge for any New Testament scholar: how exactly does one go about selecting and applying to present-day problems anthropological insights from a bygone era, which in many ways breathe a different spirit? To my mind one should at least heed the following guidelines (for which I am partially indebted to Scroggs ${ }^{6}$, without discussing them at length: 1) It should constantly be borne in mind that the New Testament dictums are aimed at their own time and cultural Sitz im Leben, and not our own. One should therefore take great care in selecting first century judgments and applying them to the world of today; 2) The principle of analogy also comes into play. We should first look for those Sitze im Leben in the New Testament that bear the closest resemblance to the current situation to which we wish to apply an ethical statement from the New Testament. Although this approach is fraught with pitfalls (e $\mathrm{g}$, there is no New Testament situation which perfectly overlaps with a modern one, even where it seems to do so) it nevertheless disciplines us to guard against over-eagerly and simplistically transferring and applying the first New Testament concept and situation that come to hand to our situation today; 3 ) The relation between ethics and eschatology should never be overlooked. One of the momentous achievements of 20th century New Testament scholarship is the discovery of the eschatological motif running through the New Testament. Although many of the ethical admonitions in the New Testament have their mirror-images in the JudaeoHellenistic background of the first century, they receive a new - eschatological context and urgency in the New Testament. The New Testament writings are thoroughly pervaded by the conviction that the end of times has dawned in the advent of Christ, that believers enjoy a new state of being and that they should live a 
life worthy of this status (cf e g Mt 5-7; 1 Cor 7:29-31); 4) The effect of this eschatological awareness upon the reader is that his mind and actions undergo the same "world-switching" transformation, and that he/she adopts as his/her own this new perception of God in his relationship to humans. Thus a new mode of being results where God's will is understood anew. It opens up the possibility of rethinking the applicability of the Biblical message, most particularly in those areas where it goes against our own ethical judgments and insights; 5) Eventually we must realise that there are many areas (such as the ones we are discussing in this article) for which we shall not find direct answers ${ }^{7}$ in the New Testament. However, we should not be chagrined by this, but accept it as part of the freedom and responsibility with which the New Testament leaves us, to go our way in fear and trembling, guided only by broad principles (as we wish to expound in this article), and so many times not even having the comfort of these,

knowing that all our decisions are imperfect, shot through with deepseated and partly self-motivations. Thus at the end of our journey we face both freedom and the need for forgiveness. Fortunately, believers in Christ trust the promise and the reality of both 8 .

And this brings forward the fourth consideration, namely the relationship of Scripture to the "natural" sources of knowledge, such as the medical, social and judicial sources. With regard to sanctity of life matters they are of particular importance (although it does not fall within the gambit of this article to discuss them). When venturing detailed advice on sanctity of life matters from a Christian perspective, not only Biblical data should be considered (however important they might be - and in this case I think they are of the utmost importance), but information from other sources of knowledge is equally indispensable. In mentioning this, I do not think in dualistic terms, as though medical data are of a totally different nature and order than that of the Bible. All knowledge which truly benefits mankind, is from God - be it in the Bible or in a medical textbook. Discoveries made and insights gained in the medical and social sciences are also of a "revelatory" nature. The only difference is that the Bible's revelation is about a unique act of God: of how God incarnated himself in history - in his dealings with Israel and in the person and work of Jesus Christ - and what consequences it has for our vision of God's creation, human and non-human life. The incorporation of medical knowledge, et cetera, with regard to the sanctity of life matters should thus not be disregarded. It is as important as Biblical revelation.

The above-mentioned methodological considerations all form, collectively and separately, areas of serious debate in their own right, a realisation which has hopefully emerged from the foregoing discussion. But we cannot pursue that task 
any further, given the limited scope of this article. Rather, what follows below, is the result of a way of arguing that might be embarked upon when discussing these problematic ethical issues from New Testament anthropology, taking into account the methodological considerations mentioned.

\section{3}

\section{A NEW TESTAMENT ANTHROPOLOGICAL FRAMEWORK}

An anthropological network of mutually dependent patterns or trajectories of thought should be established which could serve as pointers for innovating thought in difficult and foreign areas. Therefore no recipes are envisaged, only reasoned points of view.

The following anthropological criteria might be identified, beginning with the more general and ending with those of more direct interest for our subject.

\subsection{Mankind as sinners}

That mankind - all of mankind - is typified as sinful, is a well-known dictum based on certain strands in Pauline thought (e $\mathrm{g} \mathrm{Rm} \mathrm{3:9-20,23;} \mathrm{Gl} \mathrm{3:22).} \mathrm{This} \mathrm{complies}$ with what Lategan calls a "low" anthropology". It means that humans - although created in the image of God - should primarily be regarded as fallen creatures, fallen from a state of glory to one of total demise, depravation and degradation. Sin stamps their very being and nature; they are incapable of glorifying God through thought and action, prone to all that is wrong and evil. Not much could or should therefore be expected of humans; any optimistic or idealistic view of humankind must be abandoned.

Western Protestant theology (Calvinism in particular) has been thoroughly permeated by this basically pessimistic view of mankind. And although one might question the one-sided emphasis this view has effected with regard to humans - at least in the afore-mentioned theological circles - it cannot be denied that it most certainly is based on a legitimate trajectory of thought on mankind in the New Testament, especially in Paul. Furthermore, his view does not only pertain to humanity in its "natural" state, that is, unredeemed people - humanity before and outside Christ - but it also applies to those in Christ. It remains an abiding attribute of all humans. In spite of the differences in interpretation of $\mathrm{Rm} \mathrm{7:7-25}$ (whether the "I" refers to Paul/humanity before or after conversion to Christ), the fact remains that it ties in with the so-called "already/not yet" scheme in Pauline soteriolugy, according to which those in Christ already share in the full redemption wrought by Christ, but still do not yet experience the final consummation of his victory, which is still outstanding. Consequently all of mankind is subject to the havoc of $\sin$ in their lives. Only, Christians have the potential to overcome (some 
of) the devastating effects of sin by walking in the Light.

What bearing does all this have on our subject? How should we view humanity from this perspective? At least three important implications flow from this. Firstly, humans are not free to choose what is good, but are subject to the rule of sin. The flesh is constantly warring against the Spirit, with the flesh having the upper-hand. Even for Christians the effect of their sinful nature is such that their judgments on tricky anthropological issues (such as sanctity of life matters) are clouded. They simply cannot (only) rely on natural instincts and insights for guidance. They are constantly in dire need of insights from another source, the Word and Spirit of God. Secondly, in spite of humans' clouded minds, they remain responsible for their views and actions. Nowhere in the New Testament do we find that they are exempted by God from the consequences of their wrong decisions. They are still held responsible and accountable for them by God ( $\mathrm{cf} \operatorname{Rm} 1: 20$ ), the reason being the prevailing fact of their being human, created in the image of God, destined to glorify God through their actions. Thus the norm for human life still remains the law of God. It needs to be heard and interpreted faithfully - together with all the necessary voices from other sources - for sanctity of life issues. We often find that the only viewpoints being voiced when these issues are discussed, are those from the fields of medicine, psychology, sociology, law, etcetera, as if they were the only revelatory sources on these matters. Thirdly, human life is not absolute. It remains under the will and judgment of God. The mere fact of human life does not constitute its prolongation under all circumstances and at every cost. In the case of an issue such as capital punishment, this consideration should at least be given its full weight. In certain circumstances human life can become so depraved and devastatingly dangerous to other human beings, that, as ultima ratio, it has to be removed from society permanently.

The point argued in this section is that humanity finds itself in bondage of sin, and that this status has dire consequences for the way we view mankind and its ability to deal with the matters under discussion in this article. Without being overly pessimistic, at least this view leaves no room for idealistic or utopian expectations with regard to humans. In the following section the other status of humanity, namely that of being in Christ, comes under scrutiny.

\subsection{Mankind in Christ}

In the previous section mention was made of the fact that if humanity is viewed as sinful by nature, we might call it a "low" anthropology (Lategan). However, as Lategan rightly continues to observe ${ }^{10}$, this low anthropology is counterpointed by another trajectory of thought about humans in the New Testament, which might be typified as a "high" anthropology. It takes its cue from the imago Dei motif of the 
Old Testament creation stories and in the exalted anthropology of Psalm 8, and is continued in the New Testament in the honorific predicates of the Son of Man. A case in point is the Christological re-interpretation of Psalm 8 in Hebrew 2:5-18. The poet of Psalm 8 is overawed by the fact that God bestowed so much glory on humans that they were made a little less than the angels, almost divine. The author of Hebrews similarly adopts this praise of humanity, but then goes his own way by commenting on a basic flaw in humans: we see so little of their majesty since they, because of $\sin$, cannot fulfill the task of kingly rule to which they have been appointed by God (2:8b). The result is that God had to intervene by sending his Son, Jesus, to be made, for a little while, a little lower than the angels (i e to be incarnated), to take the place of his brothers ( $i$ e humanity), and through pain, suffering and death to fulfill the task his brothers could not, and eventually to be crowned with glory (2:9). By this vicarious act, Jesus in principle restored the sons of God (i e humanity) to glory again (2:10). Humans now have the ability, through faith in Jesus, to realise their potential as sons of God, to fulfill their high anthropological calling and status. Thus human life is nothing but a struggle in and with Christ for repossession of its lost glory. This struggle Lategan calls a realistic anthropology ${ }^{11}$. Let us further investigate the implications of this for our subject.

In Christ, through faith, humans obtain participation in the life of God. This results in a new status: children (sons) of God ( $\mathrm{Rm} \mathrm{8:12-17).} \mathrm{They} \mathrm{are} \mathrm{now} \mathrm{a}$ new creation ( 2 Cor $5: 17$ ), and that on a personal and corporate level. Through

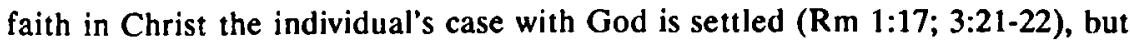
simultaneously s/he is initiated into the body of Christ, the ecclesia ( $R \mathrm{~m} \mathrm{12:5;1} \mathrm{Cor}$ 12:12-13). A new kernel of life is thus created within humanity - internally (individually) as well as externally (corporately). As such humans are individually clothed with Christ (Gl 3:27; Rm 13:14), and constantly being changed to the image of God, that is Christ ( $\mathrm{Rm} \mathrm{8:29;} 2$ Cor 3:18). (In the New Testament the Old Testament concept of the image of God undergoes a thorough Christological reinterpretation, cf $\mathrm{Col} 1: 15 ; \mathrm{Hb} 1: 3$.) But the church is also being built up in faith and increasingly conforms to Christ (Eph 4:1-16).

Various perspectives as to the way in which man participates in the life of God through Christ occur in the New Testament. The Synoptics emphasise the following of Jesus (cf Mk 1:17-18; Mt 8:18-22; etc). The disciple's life is bound up with the destiny of Jesus. In the Johannine material it is the intimate, almost mystical, relationship with Jesus, which implies that his life becomes part and parcel of that of the believer ( $c$ the image of the vine in $\mathrm{In} \mathrm{15),} \mathrm{which} \mathrm{captures} \mathrm{the}$ imagination. Paul, in his turn, stresses the corporate bond between Jesus and the believer(s), typified by the formula "in Christ". This results in a new legal status for

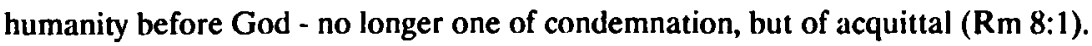

Whichever way one views humanity in Christ, for our subject one 
perspective prevails: the high esteem in which human lives are held by God. And this is not restricted to Christian-believers only. Although in the strict sense of the word it is the believer in Christ who shares in God's life, due to the universal scope of the reconciliation between God and mankind (cf 2 Cor 5:19), this (potential) status of humans becomes the angle from which all people are viewed. In principle the status of humans is not one of rejection, but of acceptance and redemption by God.

This status of necessity emphasises the responsibility of humans to live up to it, that is, to observe all God's commandments, as embodied in Jesus Christ. No wonder that the ethical exhortations in the New Testament always reflect this Christological-theological basis. It is a two-way responsibility. Firstly, one's whole being is involved in this relationship; no part of one's life is exempted (cf the socalled antitheses in the Sermon on the Mount [Mt 5:21-48] which emphasise a wholehearted attitude in the service of God; see also Mt 22:37: the all-demanding love of God). From the core of human existence a transformation is taking place which affects every part of human life. Secondly, human life is also regarded as being lived concretely in service of God. The body is viewed as the temple of God (1 Cor 6:19); Paul appeals to the believers in Rome to present their bodies as a

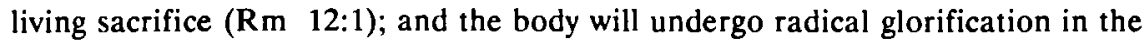
resurrection (1 Cor 15:35ff).

The point made in this section revolves around the high anthropological status of humanity in Christ. Christ serves as the focal or integration point through which all humans find their (potential) status, life and destiny. This being so, it goes without saying that one can never speak lightly of the life entrusted to humans by God, no matter what state, stage or condition it is in. All of God's actions speak of a great YES for humanity. And this can only be disregarded at mankind's own peril. Since Christ has come, one can never look at humanity in any other way than through the filter of Christ. And this holds true especially for that part of humanity to which we now finally turn: people at the mercy of others.

\subsection{The least}

Whereas the former section treated humankind in general as seen in the eyes of God, the following concentrates on a trajectory of thought running throughout the New Testament (and the Old Testament for that matter) which might be described as God's concern for the marginalised and infringed. It is not only humans as such who are the object of God's love, but particularly the lowly, the weak, the least. It concerns the status of those who have no status, no voice, no rights. This statement should be viewed concretely against the background of society in antiquity (especially in Palestine) where the rights of the ordinary individual were trampled 
upon. To understand this better, we need to take a closer look at the way in which the Jewish society in Palestine was ordered during the first century.

Broadly speaking - from an economic point of view - there were only two 12 groups: the rich (comprising about five per cent of the population and mostly situated in the cities) and the poor (about ninety five per cent, predominantly in the rural areas). A strong middle class, as in modern societies, was absent for all practical purposes. The rich comprised first and foremost the wealthy high-priestly clans, further, the Herodian family and retinue, the remnants of the older Jewish aristocracy, and prosperous merchants. An important factor in being considered rich, was land-ownership. All of the afore-mentioned groups, except the merchants, qualified in this regard. The latter, however, controlled a fair deal of the economic life of the country, and this compensated for their lack of land-ownership.

The rich were despised by the poor, the so-called Y TW that is, the people of the land. It is not so clear from the extant data exactly who this group was ${ }^{13}$. It depends from which perspective you view them. Politically, that is, from a perspective of power, these people had no rights and power concerning the political destiny of the land. Religiously speaking, they were regarded as ignorant and uninformed, particularly as far as legal prescriptions (e $g$ about prayer and tithes) were concerned. Viewed from an economic angle, however, the great common denominator was that they were poor - some less than others, but still, poor. They were tenant farmers (peasants), hired labourers, small-town artisans (e g carpenters), fishermen, beggars, and social outcasts, such as tax-collectors, hired shepherds, tanners, prostitutes, the sick and the possessed. (These social "untouchables" were sometimes collectively called "sinners", cf Lk 15:1). The הצ הצד are usually referred to in the Synoptics as "masses" or "crowds" (cf Mt 4:25; 5:1; 7:28; etc). However defined, politically, socially, religiously and economically viewed they were for all practical purposes marginalised, eking out an existence in the country side, having little or no rights and prospects.

It was these people in particular that Jesus, himself being part of them, reached out to (Lk 15:2; etc). He forcefully stepped forward into the void of their existence as the protector and comforter of the weak (cf the "programmatic" sermon of Jesus in Lk 4:18). He gave new meaning to their lives, filling them with selfesteem, "lifting them up to where they belonged", gathering them into the fold of God's people (cf Mt 5:3-10; Lk 18:9-14; Mt 21:31-32; etc). Gerd Theissen calls our attention to a special way in which Jesus did this ${ }^{14}$ : Jesus made the splendour and values of the rich and powerful available to the Tु suffice: a) Jesus took the title "sons of God", which in the Old Testament and in Roman-Hellenistic religious culture was reserved for kings, and transferred it to the people of the land. He did this, inter alia, by calling the poor "peacemakers" (Mt $5: 9 a)$. It was regarded as a typical characteristic of a good ruler to seek and 
establish peace. In that the poor were assigned the same function, they could therefore rightly be called "sons of God" (Mt 5:9b); b) In Roman-Greek culture to be free from earthly worries and generous with money and possessions was regarded as part of an aristocratic lifestyle. In the Sermon on the Mount Jesus calls upon the poor - exactly those who could not afford it - to be free from worries, because - and this is the implication - they were princes and princesses in God's palace and $\mathrm{He}$ would take care of all their needs (Mt 6:25-34). And the poor widow of Mk 12:41-44 makes a donation to the temple treasury as if she were a rich benefactress who could afford to give from the abundance of her wealth.

Another telling example of Jesus' dealings with the העד הער , is his attitude towards children. For the purpose of our argument, the latter might also be regarded as belonging to the people of the land. Children were not (yet) reckoned as worthy of the kingdom of God, since it could not be expected of them to fulfill the requirements of the law. As a result of this, their relationship with God was seen as being mediated by the father of the house. A further characteristic of children was that they (like women) were not allowed into the "court of Israel" of the temple, that is, the court for adult Jewish males; they were restricted to the so-called women's court. In an interesting article Van Aarde ${ }^{15}$ demonstrates how Jesus elevated the child's status from that of potential to full believing member of Israel. Since the second temple period a tendency had taken root in Israel to theologically broaden the temple building and covenant community. For example: women and children were forthwith included in the national assembly, and Nehemiah extended the temple's holiness to the city's walls and the city itself (cf Neh 3:1; 11:1). This tendency continued into New Testament times. The Pharisees, for example, tried to replicate the temple's holiness for ordinary life by means of their purity laws. Jesus also did this, but, as opposed to the Pharisees, he broadened the temple itself by breaking down its exclusivity. He "unbanned" the temple, so to speak, for the unclean and socio-religiously marginalised (in terms of the temple requirements) by healing the blind and the lame within the temple (Mt 21:14). And, in line with this, we learn that even children praised Jesus as the son of David in the temple (Mt 21:15). Along the same lines, Jesus opened the kingdom of God to the people of the land by using child metaphors - epitomising the qualities He was looking for in his followers: "children" (paidia, Mt 18:3), "little ones" (mikroi, Mt 18:6-14) and "the least" (elachistoi, Mt 25:40,45). And in Mk 10:13-16 Jesus sums up his Kinderevangelium by blessing the little children, thereby indicating that children need not first grow up in order to qualify for the kingdom of God; on the contrary, they already belong to the kingdom as children. What is more, if adults do not become like children, they will never enter the kingdom (cf also Mt 18:3). Thus children do not only become recipients of the kingdom in their own right, but they are designated as the norm according to which adults are allowed to enter the 
kingdom. In a self-righteous, adult and male dominated culture, this must have come as a tremendous blow to the adult (especially male) ego. In doing so, Jesus indeed effected a Weltrevolution (Theissen), turning the tables - the whole world upside down, putting first that which had been regarded as last and the least.

In his turn, Paul joins this trajectory of thought by emphasising the equality of Jew and Greek, freeman and slave, and man and woman in Christ (e g Gl 3:28). This statement of Paul was revolutionary, at least as far as women were concerned. In stressing the equality of men and women in the redeeming work of Christ, the inferior status of women in antiquity, which in effect relegated them like children - to the category of the position of women was now elevated to one of co-recipient with and co-worker of her male counterpart in the kingdom of God. No mediating function of husband, father or brother was any longer necessary. In a culture where a woman's status was dependent on her being attached to a man, this represented full liberation. The effect of this on a woman's attitude towards marriage is touched upon in 1 Cor 7 . What Paul essentially has to say, is found in the eschatological toned passage, 7:3235. According to this, a woman should not feel any compulsion to marry just because custom requires it of her; she is free to serve the Lord without the bonds and responsibilities of marriage, on an equal level with men. She is equally called to "undivided devotion to the Lord" ( $v$ 35); this is not the sole prerogative of the man. This view of women ties in with the way the Gospels portray them, highlighting their role in salvation history (e g Lk 1:28,38; 2:36ff; Mt 1:3 [Tamar], 5 [Rahab, Ruth], 16 [Mary]), and the way in which the Gospels - especially Luke - describe Jesus as paying special attention to them (e $g$ Lk 7:37ff; 10:38-42; 13:11; 21:1-4). Essentially the same picture is drawn as in the case of children: a marginalised group in society is given special treatment and a new status.

What has been put forward about the changed position of children and women in the New Testament, is intended to serve as concrete illustrations of Jesus' whole attitude and actions towards the marginalised and infringed.

The foregoing survey is sufficient for us to draw important conclusions for New Testament anthropology in general and our subject of sanctity of life issues in particular. For several years liberation theology has been - and still is - very active in exploiting the socio-political dimensions of the above observations to the full. But to my mind there is an anthropological dimension to these that has been largely neglected, and which needs to be explored and applied to a problem area such as sanctity of life matters. It is exactly those who were not reckoned as fellow human beings by the Jewish establishment of Jesus' day, that were held in such high esteem by God that Jesus declared, in the face of the Jewish elders: "the tax collectors and prostitutes are going into the kingdom of God ahead of you" (Mt 21:31). 
Where humans in their arrogance only have eyes for the grandiose, the important, the mighty, the powerful, projecting contempt and disregard for others apparently without importance, it is God who reverses the order. Those who are first will be last; those who wish to be served should become servants; those striving to enter the kingdom of heaven, should become like children. He, the God of the universe, the head of the cosmos, thought nothing of it to empty himself into human form (Phlp 2:7). He is the one caring for the sparrow and the lilies of the field, and counting the hair of one's head. Indeed He is the God of mighty works, but he is also the God of the infinitesimal small and seemingly unimportant. This sensitivity of God for seemingly rejected and abandoned life forms is in stark contrast with the arrogant way in which people sometimes tend to argue life and death issues without regard and sensitivity for the mysteries of life, as if we had all the answers. Not for nothing the fruit of the Spirit is love...patience...gentleness, and self-control (Gl 5:22).

\section{CONCLUSION}

To my mind the above anthropological argument from the New Testament might serve as a framework which could guide our thoughts in problematic ethical areas, such as sanctity of life matters. It goes without saying that human life is regarded as of high value and merit in the New Testament, and must not be subjected to willful and arbitrary manipulating. Indeed, human life is sacred. With this principle in mind, the Christian-believer should make decisions from a sanctified and sharpened conscience which will promote and protect life, and give the benefit of the doubt to people, especially those at the mercy of others, and/or without voice. This requires a sensitivity to the concrete situation, taking into account all relevant data, without relapsing into casuistry.

\section{NOTES:}

1 Slightly adapted and expanded from a paper delivered at the Theological Conference of the Reformed Ecumenical Council in Athens, May 1992.

2 By using the word "sacred", the idea is put across that we find a motif running through Scripture which so portrays human life that it may not be wasted and disposed of indiscriminately, but must be held in high regard.

3 Of the many books and articles on this subject, I mention the following: $\mathrm{D} \mathrm{H}$ Kelsey, The uses of Scripture in recent theology, Philadelphia 1975; T W Ogletree, The use of the Bible in Christian ethics, Philadelphia 1983; R B Hays, "Scripture-shaped community. The problem of method in New Testament ethics", Interpretation 44 (1990), 42-55; L S Cahill, "The New Testament and ethics", Interpretation 44 (1990), 383-395; S E Fowl \& L G 
Jones, Reading in communion. Scripture and ethics in Christian life, London 1991; R Scroggs, The text and the times. New Testament essays for today, Minneapolis 1993 (chs 1, 11, 14-15).

4 A few passages do have some bearing upon these issues, e g Mathew 5:21-25, 38-48; 7:1-6; John 7:53-8:11; Romans 12:19-21; 13:1-7, but since the focus of this article is upon anthropology, I shall not discuss them here.

5 In the context of this article "anthropology" is seen as theological reflection on the nature of human existence.

6 Scroggs, op cit, 207-211. See also H C van Zyl, "Die grondslag van Paulus se etiek in die eerste Korintiërbrief: Riglyne in die hedendaagse moraliteitsverskuiwing" in: Geloof en opdrag. Perspektiewe op die etiek van die Nuwe Testament, C Breytenbach \& B C Lategan (eds), Stellenbosch 1992, 129-130. (Scriptura S9a).

$7 \quad$ Strictly speaking there is no such thing as "direct answers" in the New Testament (or the Bible for that matter); all "answers" are (mostly unwittingly) filtered and screened by many subconscious processes for our situation today.

8 Scroggs, op cit, 211.

9 B C Lategan, "New Testament anthropological perspectives in a time of reconstruction", Journal of theology for Southem Africa 76 (1991), 88.

10 Lategan, op cit, 88-91.

11 Lategan, op cit, 90.

12 For purposes of this article we leave out the actual rulers of Palestine, viz the Roman military officials, who governed Palestine in close liaison with the rich among the Jews.

13 Compare for example the expositions of A G van Aarde, "Jesus en die sosiaal-veragtes", Hervornde Teologiese Studies 44 (1988), 839-842; and P H Davids, "Rich and poor", in: Dictionary of Jesus and the Gospels, J B Green, S McKnight \& I H Marshall (eds), Leicester 1992, 701-710.

14 G Theissen, "Jesusbewegung als charismatische Weltrevolution", New Testament Studies 35 (1989), 343-360.

15 A G van Aarde, "'n Nuwe-Testamentiese perspektief op die kind", Hervornde Teologiese Studies 47 (1991), 685-715. 